\title{
The Impact of Organizational Culture on Employee Engagement in Saudi Banks
}

\author{
Mohammed Al Shehri ${ }^{1}$, Patrick McLaughlin ${ }^{2}$, Ahmed Al-Ashaab ${ }^{3}$ and Rashid \\ Hamad $^{4}$ \\ ${ }^{1}$ Cranfield- United Kingdom- Cranfield University \\ ${ }^{2}$ Operations Excellence MSc- Cranfield- United Kingdom- Cranfield University \\ ${ }^{3}$ Lean Product Development- Cranfield- United Kingdom-Cranfield University Manufacturing \\ Department -School of Aerospace, Transport and Manufacturing \\ ${ }^{4}$ Safety \& Human Factors, SATM- School of Aerospace, Cranfield- United Kingdom-Cranfield \\ University Transport and Manufacturing
}

Correspondence should be addressed to: Mohammed Al Shehri; M.a.alshehri@cranfield.ac.uk

Received date: 12 June 2017; Accepted date: 31 October 2017; Published date: 25 December 2017

Academic Editor: Fatima Afsheen

Copyright (c) 2017. Mohammed Al Shehri, Patrick Mc Laughlin, Ahmed Al-Ashaab and Rashid Hamad. Distributed under Creative Commons CC-BY 4.0

\begin{abstract}
The Saudi Banking industry is an important component of Saudi Arabia Economy. In the view of the high volume of business activities, Saudi Banks are keen to encourage employee participation and employee engagement. These behaviours will help banks in managing their business activities and business development. This paper provides a stimulating opportunity to advance the knowledge of the link between organizational culture, and employee engagement, at Saudi banks. This research paper will investigate the organizational culture enablers and inhibitors of employee engagement in Saudi Arabia Banks. This research is a qualitative approach; the method used is a grounded theory. Data collection adopted an issue focus approach. Interviews were conducted with Bank line managers, and subordinates. The results revealed that the enabler factors that contribute most to employee engagement enablers were training and development, organizational communication, reward, and recognition. Results revealed that Islamic culture has an influence on employee engagement in Saudi banks. This influence shown was in Noninterest bearing transactions, and the female segregation rule.
\end{abstract}

Keywords: Employee Engagement, Organizational culture, Saudi Arabia, Saudi Banks.

Cite this Article as: Mohammed Al Shehri, Patrick Mc Laughlin, Ahmed Al-Ashaab and Rashid Hamad (2017), "The Impact of Organizational Culture on Employee Engagement in Saudi Banks", Journal of Human Resources Management Research, Vol. 2017 (2017), Article ID 761672, DOI: $10.5171 / 2017.761672$ 


\section{Introduction}

\section{Research Background and motivations}

Pritchard (2008) emphasized that one of the challenges that faces organization is marinating engaging employees. Furthermore, employee engagement influences organizational performance, and productivity, (Levinson, 2007). The main aspect of the problem is to find out in which circumstances employees are engaged, as well as in which circumstances employees are disengaged (Wildermuth \& Pauken, 2008). Researchers have linked employee engagement directly with organizational culture (Williams, Dobson, \& Walters, 1989). Organizations are keen to understand why, in certain circumstances, employees exhibit different engagement levels (Corace, 2007). Employee engagement optimized organization productivity and revenue, (Lloyd, 2008). Employee engagement is a major area of interest within the field of banking industry in Saudi Arabia. Therefore, researchers are motivated to understand the influence of organizational culture on employee engagement in Saudi Banks (Ahmad \& Aldakhil, 2012).

Saudi Arabia

The Kingdom of Saudi Arabia (KSA) is one of the Gulf countries. Islam is the religion in Saudi Arabia. Islam is reflected in all aspects and levels of society: economically, socially and even politically (Harper \& Subanthore, 2007). Saudi Arabia gained a prominent position in Islamic countries by having two holy mosques that millions of Muslims visit to perform their Hajj and "Umrah" during the year. The second factor that gave Saudi Arabia its important economic position was the oil discovery. Saudi Arabia was one of the countries in Hofstede 6-D cultural dimension Model ( Hofstede, \& Minkov, 2010), dimensions were identified as existing at the individual level, as well as at the national level. Hofstede categorized national culture into seven dimensions: Power Distance, Uncertainty Avoidance, Individualism vs.
Collectivism, Masculinity vs. Femininity, Long Term Orientation Index, Indulgence versus Restraint Index, and Monumentalism versus Self-Effacement. In Power Distance dimension Saudi Arabia scores 95, which is considerably high, people with such score tend to accept a hierarchical order in which everybody that is preserved to everybody without any justification. Organization Hierarchy is perceived as inherent. Furthermore, centralism is popular, and subordinates' role is to do what the leader asks them to do. Saudi Arabia score in individualism dimension reveals that it is a collective society, the score was 25 , such score indicates that society has long term commitment to the group or extended family with high loyalty to these extended groups or families. The relation between employees and leaders is like family relationship. Masculinity score for Saudi Arabia was 60; this indicates that Saudi Arabia is masculine society; in this type of society leaders are influential and confident. In Uncertainty avoidance dimension, Saudi Arabia score was 80, which means that the Saudi society is uncertainty avoidance society. In this type of society, beliefs and behaviours is an important aspect. The need for rules in this society is based on emotional needs. Security is one of the essential needs for people in this society (Hofstede et al., 2010).

\section{Saudi Banking Sector}

The Saudi Banking industry includes twelve banks; three of these banks are joint venture banks. These banks are; The Saudi British Bank, Banque Saudi Fransi (BSF), and Saudi Hollandi Bank. In addition to local banks, there are Banks from the Gulf region, and other foreign banks. Saudi commercial banks provide retail banking, corporate banking, investment services, brokerage, derivative transactions, and other retail, and corporate related transactions,(Iqbal \& Molyneux, 2005). Saudi banking mostly provides Islamic products, through a strong Islamic banking 
system. The Islamic banking system is based on non-interest banking that complies with Islamic law "Sharia", (Kettell, 2011).

\section{Employee Engagement}

Shuck and Wollard (2009) defined employee engagement as a new employment context that describes a positive relationship - both emotional and cognitive - by an employee towards the output of their organization. The term has also been described as the willingness and flexibility of employees to apply their skills to organizational success (Perrin's Global Work Study, 2003). Employee engagement describes a situation in which an employee's actions, thoughts and attitudes are in line with that of their employer (Shuck and Wollard, 2009). It is the situation in which achievement of organizational goals and organizational efficacy contributes to feelings of personal fulfilment (Maslach et al., 2001). The contrary state could be described as cynicism, exhaustion, burnout and inefficacy (Maslach and Leiter, 2008). Employee engagement is dependent on how well connected and committed to an organization staff members feel (Demovsek, 2008). When there is full employee buy-in to the organizational strategy and all staff is driven to achieve organizational success, true engagement is possible. In these cases, employees are happy to work for and promote their organization, and what they experience goes beyond work satisfaction. Employee engagement has been linked to improved performance, productivity and attendance, as well as increased retention (Caplan, 2013). One study conducted on GCC region found that engaged employees not only demonstrate greater productivity, they also directly endeavor to support their organizations (Singh et al., 2012). Employers face some difficulty in determining the definition and value of employee engagement, as there is such a variety of literature on the subject (Saks and Gruman, 2014). A series of research was carried out in India in 2010 to evaluate employee engagement levels that found $37 \%$ of employees to be engaged (Blessing and White, 2011). There was variation according to the following demographics: gender, structure and size of enterprise, and job function. Higher levels of engagement were reported among older and married staff. Those employed in banking were found to have low engagement, while those employed in the healthcare and chemical sectors were found to have high engagement. Indian managers noted motivation was derived from the right success elements in a job: $28 \%$ pointed to a career path accompanied by employee development; $21 \%$ pointed to appropriate skills and abilities; and 15\% pointed to the importance of being challenged on the job (Blessing and White, 2011).

The research on the topic of employee engagement is relatively new, there is a need to do more work to determine its roots, progression and consequences (Vanc Rooy, 2011). Several researchers have covered the topic using different terminology, which requires illumination (Frese, 2008). The contemporary ideas and measurement tools may require further work and evolution (Saks, 2008; Seppäla et al., 2009; Klassen et al., 2012; Fearon et al., 2013). Though disagreement exists on all levels, the majority of work on the subject agrees that engagement is a multifaceted paradigm (Kahn, 1990; Harter et al., 2002; Schaufeli, Salanova, González-Romá \& Bakker, 2002, 2006; May, Gilson \& Harter, 2004; Saks, 2006, 2008; Lockwood, 2007; Cheese et al., 2008; Frese, 2008; Macey \& Schneider, 2008; Masson et al., 2008; Seppäla et al., 2009; Robertson \& Cooper, 2010; Christian et al., 2011; Parker \& Griffin, 2011; Gruman \& Saks, 2011; Van Rooy et al., 2011; Mills et al., 2012). While researchers agree on the paradigm's complexity, they disagree on the best means of defining it and on what constitutes it (Dalal, Brummel, Wee \& Thomas, 2008; Frese, 2008; Griffin, Parker \& Neal, 2008; Hirschfeld \& Thomas, 2008; Macey \& Schneider, 2008; Saks, 2008; Robertson \& Cooper, 2010; Schaufeli \& Salanova, 2011; Juniper, 2012). There is also disagreement as to whether engagement results in positive behaviors or an inadequate atmosphere that some 
may seek to change ( Frese, 2008; Masson et al., 2008; Parker \& Griffin, 2011). There is agreement among researchers that the paradigm of engagement shares some overlap with other employee-focused elements (Kahn, 1990; Endres \& Mancheno- Smoak, 2008; Frese, 2008; Masson et al., 2008; Newman \& Harrison, 2008; Robertson \& Cooper, 2010; Parker \& Griffin, 2011). Such overlap may invalidate discriminant validity (Saks, 2008; Harter \& Schmidt, 2008; Newman \& Harrison, 2008). Despite this, one piece of research found discriminant validity to be suggested within the Macey and Schneider (2008) framework (Christian et al., 2011).

\section{Organizational Culture and Employee Engagement}

Organizational culture has been shown to propel employee engagement (Lockwood, 2007; McBain, 2007). Employee engagement is more likely to occur in a friendly and supportive work environment. Such engagement is facilitated by appropriate compensation and benefits for employees. It is also fostered by alignment to organizational mission and vision statements, positive peer treatment, and a policy of work-life balance. Social Exchange Theory can be used to demonstrate the connection between organizational culture and employee engagement. Such a connection is a two-way relationship between the organization and its employees (Robinson et al., 2004). When employees feel they are deriving benefit from their employer, they feel a responsibility to return the favors through their work ethic. The Social Exchange Theory implies this when it notes that a longstanding and mutually beneficial relationship will result in loyalty, trust and commitment over time (Cropanzano and Mictchell, 2005). Other research has noted that employee engagement is linked with perceived organizational support (POS) (Sacks, 2006; Ram \& Prabhakar, 2011; Shuck, 2010). Like organizational culture, POS is seen as a value to employees through the realization of good values and good managerial operations. Employees experiencing good organizational culture feel psychologically safe. Thus, research correlates employee engagement with psychological safety (Kahn, 1990).

There are two major aspects of organizational environment and culture in Saudi Arabia. The first aspect concerns the fact that Saudi nationals with public sector administration positions are compensated in terms of high salaries, health care, and educational bursaries, among other remunerations (Madhi \& Barrientos, 2003; Sadi \& Al-Buraey, 2009). The second aspect concerns the fact that most non-Saudi nationals can be found employed within the private sector. They have restricted employment visas and are subject to temporary residence within Saudi Arabia. All employees are subject to Islamic values, Sharia laws and Arab cultural norms (Dadfar et al., 2003). According to Hofestede (1980), The Saudi Arabian culture can be defined in terms of uncertainty prevention, power distance and collectivism (Alkhaldi \& Wallace, 1999; Robertson et al., 2001).

Organizational culture in Saudi Arabia is organizationally specific (Al Raisi et al., 2011). There is currently resistance from Arabian businesses to place value on employee attitudes and personal behaviours in terms of their impact on organizational outputs (Al-Raisi, 2011). This is in line with Arab culture as a whole, which is not open to change or alterations to the existing status quo. Current literature notes a research gap on the impact of employee behaviours in Arab countries, and particularly in Saudi Arabia (Al-Raisi et al., 2011). The main body of research in this field has been carried out in the United Kingdom and the United States of America. This body of research has found satisfaction and perceived discrimination to carry the greatest weight in regards to employee work-related behaviors (Ozer \& Gunluk, 2010). The connection between personality characteristics and employment satisfaction has also been explored through the lens of human resource management (Furnham et al., 2002). Although there is some work concerning the correlation between satisfaction and reward, very little research exists concerning the correlation between work-related attitudes, job performance and employee engagement . 
With this gap in mind, this research aims to critically focus on the role of Saudi Arabian organizational culture in order to explore how it impacts employee engagement. Furthermore, this research will provide Saudi banks with evidence on the benefits of having high employee engagement, and how engaged employees contribute to organization accomplishment.

\section{Research Methodology}

This qualitative research used Grounded Theory, which is an approach to developing theory that is "grounded in data systematically gathered and analyzed" (Strauss \& Corbin, 1994).The data analysis unit was the individual speaking in a group. The results were validated by observations, and then by comparing the findings with those in the literature. The aim of conducting the study is to promote the pilot study outputs and enrich the data pool with larger sample. Moreover, exploring the potentials additional factors will be emerged. One of the features associated with this study is that the sample covers female employees, which contributes to the diversity of data pool.

In this study, 7 banks were visited; 28 interviews were conducted with managers in these banks, along with their subordinates. The outcomes of this study helped in obtaining knowledge regarding enablers and inhibitors of employee engagement according to the views of those in these organizations. In addition, this study enabled the researcher to observe the banks' programs in maintaining employee engagement and provided insights into issues to be considered while developing the framework this research will be producing.

\section{Ethical issues:}

The ethical approval was obtained prior to the study. Moreover Cranfield university ethical principles were considered, the interviews were anonymous, and interviewees were free to withdraw at any time during the interview. Furthermore, permission from organization and interviewees were obtained to record the interview. It was emphasized to participant organizations that the data collected were to be used solely for academic purposes.

\section{Research Setting}

In view of the fact that most banks' head offices are in the western and central provinces, the study took place there. Banks were selected according to the ease with which they could be accessed.

Two questions were used for the issue focused interviews:

- What incidents do you remember when employee engagement went well?

- What incidents do you remember when employee engagement did not go well?

Interviews were conducted as open discussions and guided by the participant (Glaser, 1998). This enabled the researcher to capture a sufficient depth of data. Interviews started with an open question and interviewees were encouraged to keep talking about the issue, which in this study is employee engagement in their organizations. Digital recordings were used and some notes were taken during the interview for subsequent verification. The text was then re-coded as new concepts emerged and patterns detected. The interviewees were selected from banks' head of functions and their subordinates. Interviewees were from different roles and in different regions.

\section{Data Collection}

As this research is adopting the grounded theory approach, the intervention of the researcher was kept to minimum, and the interviewees were given the freedom to express their views about employee engagement in their organization. This Main study used un-structured interviews, the interviewer is aware of the scope of the research. Utilizing such a method allows 
the researcher to capture any elements of culture that influence employee engagement that might not be found in all organizations, and at the same time make it possible to limit the research area .

\section{Sampling}

Theoretical sampling is the method used for data collection in Grounded Theory; that is to say, the sampling is based on theoretically relevant constructs. It enables the researcher to select subjects that maximize the potential to discover as many dimensions and conditions related to the phenomenon as possible (Strauss \& Corbin, 1990). Therefore interviewees were chosen on consideration of their potential knowledge about engaging employees.

\section{Data Collection}

For the data collection an issue focused approach was adopted (Sackmann 1991). This approach ensures that the researcher influences the direction of the interview as little as possible. The interviews used to capture the data in this research were unstructured in type. Unstructured interviews allow the researcher to capture any elements of culture affecting employee engagement that might not be found in all organizations. Furthermore, they give the interviewees the freedom to express their views of the organizational culture that influences employee engagement without the predetermined interpretation of the researcher. Interviews were recorded electronically. They were fully transcribed verbatim for data analysis. After precisely reading each interview's transcript and its interim analysis, planning for conducting the next interview was made.

\section{Coding}

Data analysis was carried out using Strauss and Corbin's model of analysis through constant comparative method, performing three levels of open, axial, and selective coding. The relationship between categories and the leading core category was identified through the process. In addition, throughout the process, the memos were written and diagrams developed to facilitate the visualization of data for better conceptualization. Theoretical saturation was achieved after conducting 39 interviews and was confirmed after completing 6 more interviews with women. The rigor of study was verified through prolonged engagement in data gathering and member validation of codes meanwhile, in order to verify the interpretations, the codes and emerging categories were discussed with the supervisors who had good expertise in conducting and supervising qualitative research.

Coding commenced by converting the recorded interview scripts to Word documents. The second stage was breaking down the data to capture the behaviour stated in the interview scripts. More emphasis was placed on the words that reflect the influence of culture on employees' behavior. NVivo software was used for fracturing the data scripts into codes. The software was useful for storing the interview records on the system to be used in the coding stages as well as for helping to sort the scripts into different coding.

\section{Focus Group Discussion}

Group discussion enables the research participants to set out their views about cultural values and beliefs (Sackmann, 1991). The purpose of the focus group discussion is to allow participants to divide employee engagement enablers and inhibitor codes into categories. The focus group meeting was attended by four participants from Saudi banks. The role of the researcher in this session was that of a facilitator; his intervention was kept to a minimum and he took part in the discussion on a level with the other participants. Furthermore, in accordance with Alderfer \& Smith (1982), researcher bias and assumptions were avoided by keeping the researcher's contributions to a minimum. The main outcome expected from the meeting was the determination of the core phenomena of employee engagement enablers and inhibitors in Saudi banks.

\section{Results and Findings}


The researchers have completed the process of coding the recorded 16 hours interviews, and converting theses in to 180 pages interview scripts. The analysis of the 28 interview scripts formed 45 codes (see table 1). The results of the study revealed that the enabler factor that contributes most to employee engagement was employee satisfaction at work training, achievement recognitions and development (see figure 1). Moreover During the interviews these two factors were mentioned in 28 occasions (see table 2 ). The study results reveal that the second highest factor is Jobs in line with employee tendency, this factor was mentioned in 27 occasions (see table 2). Whilst, effective organization communication polices, financial reward, opportunity for development, and empowerment \& support were equally mentioned in 26 occasions (see table 2). The findings revealed employee Factor is associated with the influence of Islamic culture on the organizational culture of Saudi Banks. These are the banking system regulations and female segregation; both of them must comply with Islamic law (Shar'ia). The study also revealed that resilience within groups is one of the enablers for employee engagement in Saudi Arabia (see Table 1).

\section{Results Reliability}

Inter- rater reliability was used to examine the degree of the results' constancy. Interrater reliability is a significant tool to avoid researcher bias. Inter-rater reliability also offers validation for the study that results are not individual interpretations (Bland, and Altman, 1986). The Inter-rater procc was done by a co- researcher in the Cranfield University known in the Interrater process as (Rater2). Samples of $10 \%$ of the results were assigned to (Rater2) to compare the two results. The reliability of inter - rater percentage indicated $0.97 \%$ of agreement between the two raters which is an acceptable percentage.

\section{Themes}

The participants from Saudi banks built the relationships between the codes. During the meeting the researcher faced some challenges. One of the main challenges was the variation of views among participants about the labeling of the themes (see Figure 2 ). The role of the researcher was to facilitate the route to an agreement. The participants emphasized that codes can be categorized into the following themes:

\section{Competency and skills Development}

The research findings revealed that training and development in Saudi Banks is one of their highest enablers. Any organization that provides development opportunities, and uses the skills of its workers tends to engage them more (Constable, Coats, Bevan, \& Michelle, 2009). The interpretation of such behavior is that the organization becomes a source from which employees' interpersonal preferences can be satisfied. Saudi employees also tend to be more engaged in those banks that provide a learning and development environment of this kind. As stated by a senior manager in a Saudi investment bank: "When the organization provides employees with opportunities to be developed, employees tends to stay with the bank". Furthermore the training and development factor may be based on the fact that Saudi economic status enhances the ability of Saudi banks to allocate resources to provide training and development opportunities. Employees who are offered the opportunity to learn new skill have their needs met; their satisfaction levels and engagement rise in consequence (Vance, 2006).

\section{Management policies and procedures}

The second highest quoted enabler mentioned by the study interviewees is the organization's level of communication. The relationship between leaders and employees, or subordinates, has been examined in previous research; in the literature, leadership definitions revolve around the relationship between leaders and their followers (Kesby, 2008). Leaders are keen to establish a culture of engagement by allocating considerable time and effort to achieving the desired level of engagement (Lawrence, 2007). Internal communication is an important 
tool in establishing trust between leaders and their staff, which ultimately develops the organizational culture to maintain Employee engagement in order to optimize organization productivity and revenue, (Lloyd, 2008).

The Saudi work setting is based firmly on interpersonal relationships that affect the employees' careers (Idris, 2007). Furthermore, it may influence the sort of employee involvement and participation in the work process that will lead them to be more engaged. Saudi society is moving gradually towards increased professionalism at work. This will limit the effect of interpersonal relationships on organizations' outcomes. However, Saudi society still resists professionalism with regard to interpersonal relationships, because it suspects them of creating a more materialistic society.

\section{Motivation; Reward and Recognition}

The results indicate that reward is an important enabler for Saudi banks' employees. The wealth of Saudi banks enables them to motivate their employees through offering high wage packages. In this regard, Vance (2006) stresses that "Compensation (rewards and benefits) can powerfully influence employee engagement". Rewards are considered to be one of the essential drivers of employees' motivation. One of the main aspects of commitment that an organization can offer is its willingness to develop well designed compensation and benefits programs (Dessler, 2005). Recognition and reward is a valuable strategy that organizations can use to improve engagement levels (Vance, 2006).

\section{Fairness in the workplace}

In contrast, the study revealed that unfairness is the highest inhibitor quoted by interviewees. Saudi culture is partially based on personal relationships, which can be a cause of unfairness. As stated by one of the study interviewees (an organizational development manager at the Saudi Investment Bank): "Unfairness in opportunities to grow and to be developed makes employees tend to withdraw from involvement in organizational activities, or in some cases leave the bank". Maslach \& Leither (2008) stress that fairness is a crucial stimulus for employee engagement; in contrast, he added, unfairness will result in employee burnout.

\section{Employees' psychological ownership}

In the responses of the study interviewees, job content mismatch is the second most often cited inhibitor. As stated by a Senior Manager at the National Commercial Bank, "Employees will be engaged once their job has certain job characteristics that meet their expectations and provide the opportunities to use their skills". Job characteristics are among the most significant drivers; they encourage employee engagement (Christian, Garza, \& Slaughter, 2011). Furthermore, job autonomy, skills diversity, learning opportunities and career development are all examples of job attributes that improve employee engagement (Bakker \& Demerouti, 2007). Engaged employees are more interested in the types of job that offer a greater challenge, as well as providing room for improvement and an opportunity to use their interpersonal skills (Crawford, Duckworth, Vignoles, \& Wyness, 2010). This view is supported by Macey et al. (2009) who write that the association between individual objectives and the organization's goals stimulates employees to be more engaged. During the interview, a senior manager at the National Commercial Bank stated: "Jobs that match employees' personal agenda will definitely engage them.

\section{Diversity Management}

The study results revealed that employee engagement inhibitors are fairly closely associated with the influence on Saudi banks' organizational culture of Islamic culture. The inhibitors arise most obviously from the Islamic view of female segregation, and bank transactions that must eschew the exaction of interest. Religion is the dominant influence on Arab culture (Kalliny \& Gentry, 2007). The culture of most Islamic countries is rooted in Islamic principles that shape their way of life and influence their social practices 
(Branine, Pollard, 2010). Furthermore, all behaviours and values rest on Islamic principles (Al-Shaikh, 2003). Saudi Arabia is considered the center of the Islamic world and culture, and Saudi Arabia is heavily infused with Islamic culture. The Islamic banking system is the dominant banking system in Saudi Arabia. Many products have to comply with the Islamic system that is based on banking transactions which charge no interest.

Saudi traditions are also heavily influenced by Islamic culture (Al-saggaf, 2004). The country implements Islamic principles (Shar'ia) in all aspects of life, whereas in other Arab countries they are sometimes not fully implemented (Hickson \& Pugh, 1995). The Islamic banking system is the dominant banking system (obeying Shar'ia) and financial products have to comply with its prohibition of interest. Another Islamic influence on the work place in Saudi Arabia is the gender "segregation"; law which means that females are not allowed to share offices with male employees. Previous research regarding females working in groups concerned the physical and emotional factors that influence their contribution to and effectiveness in these groups. Although Al munajjed (2010) stated that Saudi women are not fully used in the Saudi workforce, the segregation rule is in line with Article 4 of the Saudi Labor Code, which emphasizes compliance with Shar'ia.

This article states that "both the employer and the workman shall comply with the dictates of Islamic Shar'ia". The issue of female segregation is not entirely for religious motives. The interpretation of female segregation varies among Islamic scholars in different countries. Some Islamic scholars deduce it as a requirement that a female and a male should not remain alone in a particular place. Scholars explain this view as a precautionary rule to prevent illegal affairs outside marital relations. Other scholars interpret the rule as a requirement for total segregation, regardless of whether people are alone or in groups. In Saudi Arabia, a debate about certain religious laws has arisen. The debate concerns whether these laws derive from a pure religious source (the Qur'an and the Hadith of the Prophet Mohammed), or if they are derived from society's interpretation of these laws. The segregation rule may also affect female resilience within groups, which affects their cohesion and harmonization. Finally, one of the inhibitors of employee engagement that was quoted during the interviews was the lack of resilience within groups. The demography of these groups influences the level of employee engagement within them (Barkhuizen and Rothmann, 2006). This inhibitor may owe its endurance to the fact that each of Saudi Arabia's five provinces has its own subculture. The greatest variation between these subcultures is that between the Western and Central provinces. Jeddah is the main city in the Western province, and is known as Saudi Arabia's gateway to the world. Jeddah's subculture is influenced by the huge numbers of people from around the world who come to the city. Pilgrims come to Jeddah on their way to visit the holy places in Makkah and Medina. Jeddah's subculture results from a mixture of cultures. The Central province, however, is more exposed to the culture of the GCC countries, which is categorized as more "reticent". This variation may result in the formation of a minority in some work groups. Segal (2009) stressed that having a minority within a group influenced the level of engagement in this monitory, and ultimately the outcomes of the whole group.

\section{Study limitations}

Although the research has attained its stated aim, it has some associated limitations. Due to time constraints, the number of interviewees had to be limited; consequently the results of the study cannot be generalized until they are based on a larger sample.

\section{Conclusion}

It is apparent from the research that Saudi Banks employees prefer jobs that match their preferences, and they will be motivated to be more engaged by the opportunities that a job provides them 
opportunities to use their competencies and skills. Additionally, employee engagement was also found to be influenced by the societal impact of Islam on Saudi Arabia's culture. Al Anazi and Rodriguez (2003) explained that a more self-cantered culture has emanated from the ethical standards of Western society, while more communal ethics are apparent in Saudi Arabia and its Eastern orientation. Idris (2007) determined that workers' long-term prospects are largely determined by individual relationship within Saudi Arabia's work places. Nevertheless, employers' activities are becoming slightly less influenced by individual relationships, as a consequence of stronger professional traits being in evidence in Saudi Arabia's social and economic spheres. Even so, acquisitive values are considered to emanate from an increase in professional standards, thus individual interactions are still favoured within Saudi Arabia.

Table 1 : Employee Engagement Factors in Saudi Banks

\begin{tabular}{|c|c|c|}
\hline No & Factors & Definition \\
\hline 1 & $\begin{array}{l}\text { Adjust to different } \\
\text { regional sub - cultures }\end{array}$ & $\begin{array}{l}\text { Saudi Arabia consists of } 5 \text { provinces; each province has its own sub } \\
\text { culture, employees may not be able to cope with the other sub cultures. }\end{array}$ \\
\hline 2 & $\begin{array}{l}\text { Islamic view - Non } \\
\text { interests bearing } \\
\text { transactions }\end{array}$ & $\begin{array}{l}\text { Saudis have a belief that makes them reluctant to work in conventional } \\
\text { banking associated with transactions. Avoiding interest transactions may } \\
\text { prevent employees from being engaged in certain jobs. }\end{array}$ \\
\hline 3 & $\begin{array}{l}\text { Measurable Tools and } \\
\text { Techniques to measure } \\
\text { Employee and customers } \\
\text { Satisfaction }\end{array}$ & $\begin{array}{l}\text { Organizations may use tools to measure the level of employee } \\
\text { Satisfactions. Survey is one of these tools. Survey results help } \\
\text { organizations in developing programs that fit for their engagement level. } \\
\text { Furthermore, it helps the organization to have a competitive engagement } \\
\text { culture. }\end{array}$ \\
\hline 4 & $\begin{array}{l}\text { Organization external } \\
\text { Image perception }\end{array}$ & $\begin{array}{l}\text { It is how society, social institutions, government organizations, segments } \\
\text { of the economy and economic powerhouses perceive the bank's image, } \\
\text { and how it influences the employees' engagement. }\end{array}$ \\
\hline 5 & $\begin{array}{l}\text { Self-Image perception } \\
\text { within the organization }\end{array}$ & $\begin{array}{l}\text { This factor refers to how employees at individual levels perceive the image } \\
\text { of the organization they work for, and how far this influences their attitude } \\
\text { and the extent of their engagement level. }\end{array}$ \\
\hline 6 & $\begin{array}{l}\text { Scientific and Objective } \\
\text { Hiring Process }\end{array}$ & $\begin{array}{l}\text { It is a selection of people who match with the organization's goals and } \\
\text { objectives, core values, communication, teamwork and integrity will } \\
\text { increase the chances of employees being more engaged. }\end{array}$ \\
\hline 7 & Strict rules & $\begin{array}{l}\text { This factor is about the strict rules organizations adopt. Such level of } \\
\text { punishment, such rules may make employees hesitate to participate or to } \\
\text { be keen to do some new tasks. }\end{array}$ \\
\hline 8 & $\begin{array}{l}\text { Government } \\
\text { Employment laws }\end{array}$ & $\begin{array}{l}\text { Saudi Government employment laws were developed to preserve } \\
\text { employee, and employer rights. However, these rules prevent employers } \\
\text { from getting red employees, even if their performance is very low. This } \\
\text { leads to employees misusing this high JOB security to perform and tend to } \\
\text { be less engaged. }\end{array}$ \\
\hline 9 & $\begin{array}{l}\text { Reluctance to make } \\
\text { decisions }\end{array}$ & $\begin{array}{l}\text { This refers to a type of employees who avoid the situation in which they } \\
\text { will be required to make decisions. Such personalities are to be anxious } \\
\text { form the consequences of their decisions. Therefore, they tend to be } \\
\text { avoiding to get involved and, eventually they will be disengaged. }\end{array}$ \\
\hline
\end{tabular}




\begin{tabular}{|c|c|c|}
\hline NO & Factors & Definition \\
\hline 10 & $\begin{array}{l}\text { Not to accept the } \\
\text { presence of } \\
\text { women in } \\
\text { organization } \\
\end{array}$ & $\begin{array}{l}\text { This factor refers to type of employee home believe that male and female are not } \\
\text { to share the same work place site. This view are routed in the Islam principles. }\end{array}$ \\
\hline 11 & $\begin{array}{l}\text { Islamic } \\
\text { segregation rule }\end{array}$ & $\begin{array}{l}\text { This Islamic rule is routed in Saudi culture and it is based on Islamic principles. } \\
\text { Females are not allowed to share the same offices with male employees. } \\
\text { Segregation rules play substantial role in limiting women participation and } \\
\text { involvement at work. }\end{array}$ \\
\hline 12 & $\begin{array}{l}\text { Lack of Talent } \\
\text { Management } \\
\text { Programs }\end{array}$ & $\begin{array}{l}\text { This Factor refers to unavailability programmes that promote developing skills } \\
\text { and competences. These programs must be embedded in organizations' policies } \\
\text { and values. }\end{array}$ \\
\hline 13 & $\begin{array}{l}\text { Negative } \\
\text { aspiration }\end{array}$ & $\begin{array}{l}\text { It is a situation when an employee has a goal to be in a certain level of } \\
\text { organization. If this goal couldn't be achieved, the employee will withdraw, be in } \\
\text { the passive side, and eventually will be disengaged. }\end{array}$ \\
\hline 14 & $\begin{array}{l}\text { Belief in } \\
\text { organization } \\
\text { mission and vision }\end{array}$ & $\begin{array}{l}\text { Employees' actions reflect their beliefs and values; this makes them more engaged } \\
\text { if they match with the organization's core values. }\end{array}$ \\
\hline 15 & $\begin{array}{l}\text { Lack of Employees } \\
\text { Career } \\
\text { Management }\end{array}$ & $\begin{array}{l}\text { This factor Refers to the situation were organization are not adopting the } \\
\text { employees career strategy, the provided a path for employees to grow. }\end{array}$ \\
\hline 16 & $\begin{array}{l}\text { Unequal } \\
\text { opportunities } \\
\text { between women } \\
\text { and men }\end{array}$ & $\begin{array}{l}\text { This factor is about the distribution opportunities for development, and growth is } \\
\text { unequal between women, and male employees. Men in Saudi Banks are more } \\
\text { exposed, and have more opportunities to be developed, and grow. }\end{array}$ \\
\hline 17 & $\begin{array}{l}\text { Leading by } \\
\text { motivation }\end{array}$ & $\begin{array}{l}\text { The behaviours of leaders, and top management in general, in performing their } \\
\text { roles in motivating employees. }\end{array}$ \\
\hline 18 & $\begin{array}{l}\text { Competency and } \\
\text { Skill Framework }\end{array}$ & $\begin{array}{l}\text { The availability of resources that enable employees to utilize, acquires, and } \\
\text { enhances the existing skills. }\end{array}$ \\
\hline 19 & $\begin{array}{l}\text { Alignment of } \\
\text { Employee and } \\
\text { Organizational } \\
\text { Values }\end{array}$ & $\begin{array}{l}\text { Employees' actions reflect their beliefs and values; that matches with the } \\
\text { organization's core values, this makes them more engaged. }\end{array}$ \\
\hline 20 & $\begin{array}{l}\text { Adherence to old } \\
\text { policies }\end{array}$ & $\begin{array}{l}\text { This factor refers to the old policies that have been adopted by the organization } \\
\text { for a long time. The organization is not able to cope with new developments and } \\
\text { update or change these policies. }\end{array}$ \\
\hline
\end{tabular}




\begin{tabular}{|c|c|c|}
\hline NO & Factors & Definition \\
\hline 21 & $\begin{array}{l}\text { Lack of clear goals and } \\
\text { objectives }\end{array}$ & $\begin{array}{l}\text { It is a condition when employees may not be aware of organization's } \\
\text { goals and objectives. As a result of such condition, employees would be } \\
\text { less interested, and engaged. }\end{array}$ \\
\hline 22 & Fair reward distribution & $\begin{array}{l}\text { The financial reward is a crucial tool the organization can be using to } \\
\text { motivate employees. The fairness of distribution of the reward makes } \\
\text { employees more engaged. }\end{array}$ \\
\hline 23 & $\begin{array}{l}\text { Observe the morale of } \\
\text { Employees }\end{array}$ & $\begin{array}{l}\text { According to the interviewees employees' self-esteem is one of the } \\
\text { employee engagement factors at Saudi Banks. They mentioned it is valid } \\
\text { due to the fact that Saudi society is more emotional and personal } \\
\text { relation concerned. }\end{array}$ \\
\hline 24 & Celebrate accomplishments & $\begin{array}{l}\text { Employees value celebrating achievements as one that motivates } \\
\text { employees to be engaged. They emphasize that celebrating can be in at } \\
\text { the individual basis or at the level of the department and organization. }\end{array}$ \\
\hline 25 & Promote ideas and creativity & $\begin{array}{l}\text { This factor is about the extent of innovations and creativity the } \\
\text { organization provides. Moreover it is about the policies in the } \\
\text { organizations that maintain and encourage employees to propose new } \\
\text { ideas, and initiatives. }\end{array}$ \\
\hline 26 & Monotony at work & $\begin{array}{l}\text { This factor refers to the type of work; a routine job makes employees } \\
\text { not interested to be involved. Routine tasks that are not associated with } \\
\text { challenges and new things to learn discourage employees to be engaged. }\end{array}$ \\
\hline 27 & Age restrain & $\begin{array}{l}\text { Age is one of the factors that interviewees believe prevent individuals } \\
\text { from being engaged. As they are not willing to be involved in } \\
\text { organization process while they are approaching retirement age. } \\
\text { Furthermore, they find it difficult to cope with new development and } \\
\text { technologies. }\end{array}$ \\
\hline 28 & $\begin{array}{l}\text { Focus on attendance rather } \\
\text { than productivity }\end{array}$ & $\begin{array}{l}\text { This situation is when organizations' policies are more concerned about } \\
\text { the disciplines than about employees' productivity. Such organizational } \\
\text { behavior will discourage employees from contributing to organizational } \\
\text { outcomes. Employees tend to be less interested and disengaged. }\end{array}$ \\
\hline 29 & $\begin{array}{l}\text { Education and professional } \\
\text { specialization }\end{array}$ & $\begin{array}{l}\text { This refers to a type of employees who avoid the situation that they will } \\
\text { be required to make decisions. Such personalities are to be anxious } \\
\text { form the consequences of their decisions. Therefore, they tend to avoid } \\
\text { getting involved and, eventually they will be disengaged. }\end{array}$ \\
\hline
\end{tabular}

Mohammed Al Shehri, Patrick Mc Laughlin, Ahmed Al-Ashaab and Rashid Hamad (2017), Journal of Human Resources Management Research, DOI: 10.5171/2017.761672 


\begin{tabular}{|c|c|c|}
\hline No & Factors & Definition \\
\hline 30 & Employees Loyalty & $\begin{array}{l}\text { It is the belief employees have towards the workplace's values and image. It } \\
\text { is also about the exertion organizations make to reinforce this in their } \\
\text { strategies. Such strategy motivates employees to be engaged. }\end{array}$ \\
\hline 31 & Unfair management & $\begin{array}{l}\text { This factor refers to the organization's management that has double } \\
\text { standards and treats its employees in an unequal way. Those in the affected } \\
\text { group of employees will be reluctant to be engaged. }\end{array}$ \\
\hline 32 & $\begin{array}{l}\text { employee -Manager } \\
\text { positive relationship }\end{array}$ & $\begin{array}{l}\text { The positive relation between mangers and employees needs to be } \\
\text { maintained in order to encourage employees to be more involved in the } \\
\text { organization's decisions, and plans. As a result of having such positive } \\
\text { relationship, employees will be more engaged in the organization's process. }\end{array}$ \\
\hline 33 & $\begin{array}{c}\text { Fair and clear principles to } \\
\text { assess performance }\end{array}$ & $\begin{array}{l}\text { Performance Management is a factor that affects employees' behaviours. } \\
\text { Good and fair performers are recognized. Whilst at the same time } \\
\text { performers with a negative attitude or passive behaviour can be } \\
\text { encouraged through performance systems. }\end{array}$ \\
\hline 34 & $\begin{array}{l}\text { Employee - organization } \\
\text { trustful relationship }\end{array}$ & $\begin{array}{l}\text { Safe environment in the Saudi Banks context refers to the trust between } \\
\text { organization and employee and among employees themselves. Moreover it } \\
\text { is about the feeling of being a member of family. The safe environment } \\
\text { attributes to not having conspiracies and offensive competitions among the } \\
\text { organization members. }\end{array}$ \\
\hline 35 & Allowances and benefits & $\begin{array}{l}\text { This factor is about the group of Non - financial rewards that motivates } \\
\text { employees to perform more. It is indicated that organizations care about } \\
\text { the employees' well-being. These allowances can be in the form of } \\
\text { children's education, paid vacation, housing etc. }\end{array}$ \\
\hline 36 & $\begin{array}{l}\text { Enthusiasm towards work } \\
\text { and the organization }\end{array}$ & $\begin{array}{l}\text { Employees are passionate about their work, and the organization they } \\
\text { work with. A tendency to respond positively with involvement to the } \\
\text { organization's decisions or procedures. }\end{array}$ \\
\hline 37 & Resistance to change & $\begin{array}{l}\text { This refers to the category of employees in Saudi banks; they are not } \\
\text { flexible to accept change projects. As a result of that, their involvement will } \\
\text { be limited and eventually they will be disengaged. }\end{array}$ \\
\hline 38 & JOB Autonomy & $\begin{array}{l}\text { The extent of choice employees are provided to enable them to make } \\
\text { decisions. And the degree of responsibility an employee has for failure } \\
\text { without any "reprimand". }\end{array}$ \\
\hline 39 & $\begin{array}{c}\text { Effective internal } \\
\text { communication Polices }\end{array}$ & $\begin{array}{l}\text { Internal communication is a process organizations use to share information } \\
\text { with employees at all organizational levels. The organization develops } \\
\text { communications platforms to share decisions, organization plans, and } \\
\text { future projects. Internal communication is an important tool leaders use to } \\
\text { engage employees. }\end{array}$ \\
\hline
\end{tabular}

Mohammed Al Shehri, Patrick Mc Laughlin, Ahmed Al-Ashaab and Rashid Hamad (2017), Journal of Human Resources Management Research, DOI: 10.5171/2017.761672 


\begin{tabular}{|c|c|c|}
\hline NO & Factors & Definition \\
\hline 40 & $\begin{array}{l}\text { Opportunities for } \\
\text { Development }\end{array}$ & $\begin{array}{l}\text { Training and development in an organization provide an opportunity for } \\
\text { employees to be developed and improve their skills, and provide them an } \\
\text { opportunity to climb the ladder, rather than be stuck at one level. }\end{array}$ \\
\hline 41 & Financial Reward & $\begin{array}{l}\text { The financial reward is a crucial tool the organization uses to motivate } \\
\text { employees. The fairness of distribution of the reward makes employees } \\
\text { more engaged. }\end{array}$ \\
\hline 42 & $\begin{array}{l}\text { Empowerment and } \\
\text { support }\end{array}$ & $\begin{array}{l}\text { The organization provides for employees to have the authority to make } \\
\text { decisions and to not just wait for approval. Organizations facilitate } \\
\text { empowerment by providing internal systems that help them to do their } \\
\text { work, and prevent a situation where the internal system does not support } \\
\text { employees. }\end{array}$ \\
\hline 43 & $\begin{array}{l}\text { Jobs in line with employee } \\
\text { tendency }\end{array}$ & $\begin{array}{l}\text { This factor refers to Individual tendency and how it matches the job the } \\
\text { employee is doing. Furthermore, it is about the capabilities of employees to } \\
\text { do job tasks. }\end{array}$ \\
\hline 44 & Achievements Recognition & $\begin{array}{l}\text { A culture that organizations maintain to reward best performers, valuable } \\
\text { suggestions and proposed projects that contribute to the organization's } \\
\text { performance. Recognition plays an important role in inspiring employees } \\
\text { to be engaged. }\end{array}$ \\
\hline 45 & $\begin{array}{c}\text { Employee Satisfaction at } \\
\text { Work }\end{array}$ & $\begin{array}{l}\text { Employees are passionate about their work, and there are tendencies to } \\
\text { respond positively to the organization's decision or procedures: this will } \\
\text { make the employees more engaged as they are satisfied at their workplace. }\end{array}$ \\
\hline
\end{tabular}


Table 2: Main Study Results -The frequency of Factors quoted

\begin{tabular}{|c|c|c|c|c|c|c|c|c|}
\hline Factor & Bank & $\begin{array}{c}\text { Bank } \\
2\end{array}$ & Bank & $\begin{array}{c}\text { Bank } \\
4\end{array}$ & $\begin{array}{c}\text { Bank } \\
5\end{array}$ & $\begin{array}{c}\text { Bank } \\
6\end{array}$ & $\begin{array}{c}\text { Bank } \\
7\end{array}$ & Tota \\
\hline Adjust to different regional sub - cultures & & 2 & & & & & & 2 \\
\hline Islamic view - Non interests bearing transactions & 1 & & 1 & & & 1 & & 3 \\
\hline $\begin{array}{l}\text { Measurable Tools and Techniques to measure Employee and customers } \\
\text { Satisfaction }\end{array}$ & 1 & & & 1 & & & 1 & 3 \\
\hline Organization external Image perception & & & 1 & 1 & & 1 & 1 & 4 \\
\hline Self-Image perception within the organization & 2 & 1 & & & & 1 & & 4 \\
\hline Scientific and Objective Hiring Process & 2 & & 1 & & 1 & 2 & & 6 \\
\hline Strict rules for punishment & 2 & 2 & & 1 & 4 & & & 9 \\
\hline Government Employment laws & & 3 & & 1 & 2 & & 3 & 9 \\
\hline Reluctant to make decisions & 3 & & 4 & & & 3 & & 10 \\
\hline Not to accept the presence of women in organization & 2 & & 4 & & & 4 & & 10 \\
\hline Islamic view - Female segregation law & 2 & 1 & 1 & & 2 & 3 & 3 & 12 \\
\hline Lack of Talent Management Programs & 3 & 1 & 2 & 1 & 3 & 1 & 3 & 14 \\
\hline Negative aspiration & 4 & & 2 & 2 & 2 & 4 & & 14 \\
\hline Belief in organization mission and vision & & 4 & 3 & & 5 & 3 & & 15 \\
\hline Lack of Employees Career Management & 1 & 2 & 3 & 1 & 2 & 3 & 4 & 16 \\
\hline Unequal opportunities between women and men & 3 & & 4 & & & 3 & 6 & 16 \\
\hline Leading by motivation & 3 & & 5 & 2 & 4 & & 2 & 16 \\
\hline Competency and Skill Framework & 5 & 3 & & 3 & 3 & & 2 & 16 \\
\hline Lack of clear goals and objectives & 3 & 4 & 2 & & 4 & 3 & 2 & 18 \\
\hline
\end{tabular}




\begin{tabular}{|c|c|c|c|c|c|c|c|c|}
\hline Fair reward distribution & & & 4 & 4 & 4 & & 6 & 18 \\
\hline Alignment of Employee and Organizational Values & 3 & 4 & 1 & 3 & 4 & 2 & & 17 \\
\hline Factor & $\begin{array}{c}\text { Bank } \\
1\end{array}$ & $\begin{array}{c}\text { Bank } \\
2\end{array}$ & $\begin{array}{c}\text { Bank } \\
3\end{array}$ & $\begin{array}{c}\text { Bank } \\
4\end{array}$ & $\begin{array}{c}\text { Bank } \\
5\end{array}$ & $\begin{array}{c}\text { Bank } \\
6\end{array}$ & $\begin{array}{c}\text { Bank } \\
7\end{array}$ & $\begin{array}{c}\text { Tota } \\
1\end{array}$ \\
\hline Observe the morale of Employees & & 4 & 3 & 4 & 5 & 2 & & 18 \\
\hline Acknowledge accomplishments & & & 4 & 5 & 4 & 2 & 3 & 18 \\
\hline Promote ideas and creativity & & 1 & 2 & & 5 & 4 & 6 & 18 \\
\hline Monotony at work & 6 & & 4 & 3 & 2 & 3 & 2 & 20 \\
\hline Employee Age-related behaviours & 4 & & 5 & 2 & 4 & 5 & & 20 \\
\hline Focus on attendance rather than productivity & 2 & 3 & 4 & & 5 & & 6 & 20 \\
\hline Education and professional specialization & 4 & & 4 & 3 & 5 & 4 & & 20 \\
\hline Employee Loyalty & 3 & 2 & 3 & & 5 & 4 & 3 & 20 \\
\hline Fairness at workplace & 6 & 3 & 4 & 3 & 2 & 4 & & 22 \\
\hline Positive relations between employee and Manager & 3 & 4 & 3 & 5 & 2 & 3 & 2 & 22 \\
\hline Fair and clear criteria to assess performance & 3 & 4 & 3 & 4 & 2 & 2 & 4 & 22 \\
\hline Organization - Employee trustful relationship & 4 & 4 & 3 & 4 & & 4 & 3 & 22 \\
\hline Allowances and benefits & 3 & 2 & 5 & 4 & 3 & 5 & & 22 \\
\hline Enthusiasm towards work and the organization & 2 & 2 & 4 & 5 & & 4 & 6 & 23 \\
\hline Resistance to change & 3 & 4 & 4 & 5 & 4 & 2 & 3 & 25 \\
\hline Autonomy & 4 & 3 & 5 & 4 & 3 & & 6 & 25 \\
\hline Effective internal communication Polices & 5 & 5 & & 4 & 5 & 1 & 6 & 26 \\
\hline Opportunities for Development & 5 & 4 & 3 & 3 & 4 & 3 & 4 & 26 \\
\hline Fair Financial Reward distribution & 2 & 5 & 4 & 5 & & 4 & 6 & 26 \\
\hline
\end{tabular}




\begin{tabular}{|l|l|l|l|l|l|l|l|l|}
\hline Empowerment and support & 4 & 5 & 3 & 5 & 2 & 4 & 3 & 26 \\
\hline Jobs in line with employee tendency & 4 & 5 & 4 & 5 & 4 & 5 & & 27 \\
\hline Achievements Recognition & 4 & 3 & 5 & 3 & 5 & 4 & 4 & 28 \\
\hline Employee Satisfaction at Work & 4 & 4 & 3 & 2 & 4 & 5 & 6 & 28 \\
\hline
\end{tabular}




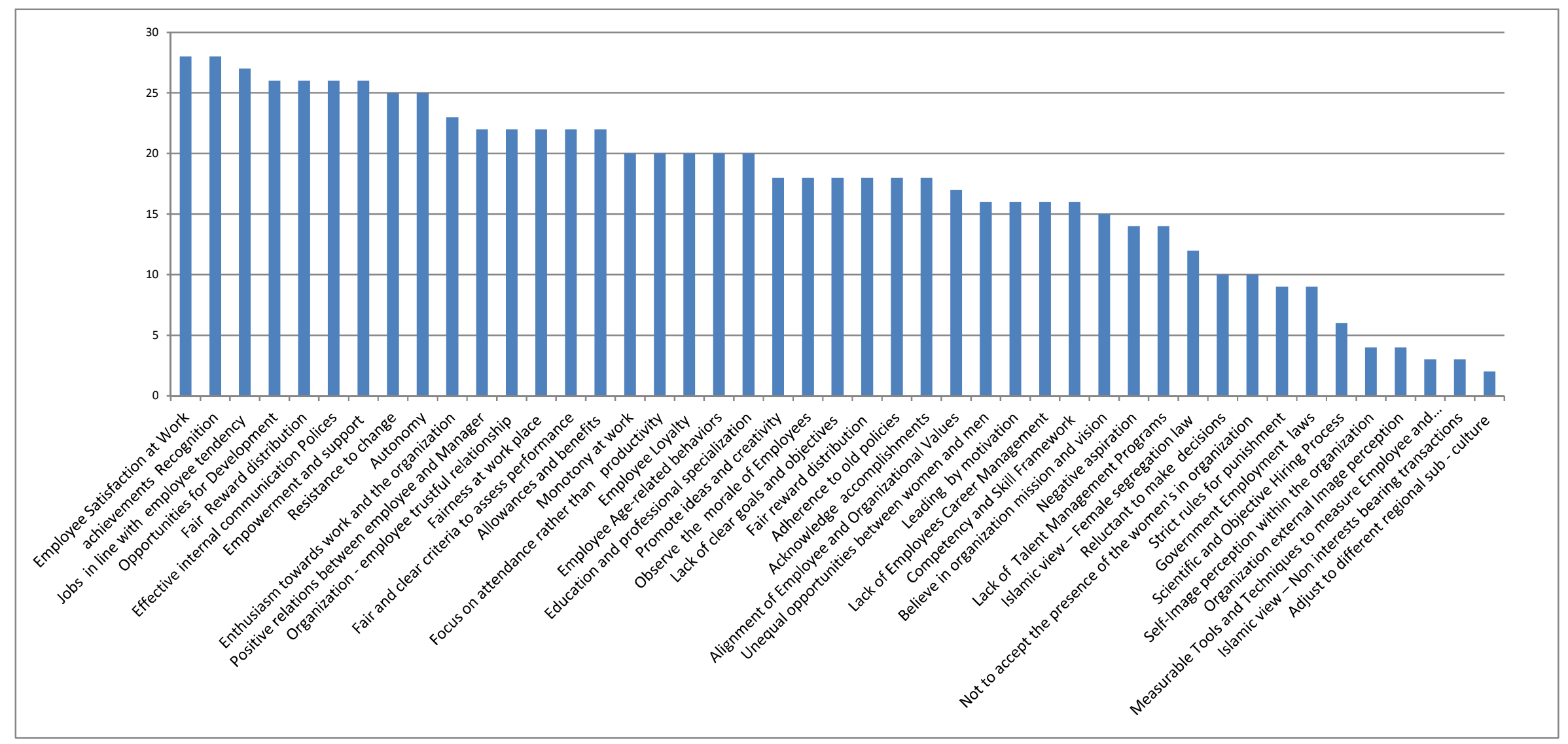

Figure 1: Frequency of Employee engagement Factors' reference quoted.

Mohammed Al Shehri, Patrick Mc Laughlin, Ahmed Al-Ashaab and Rashid Hamad (2017), Journal of Human Resources Management Research, DOI: 10.5171/2017.761672 


\section{References}

1. Ahmad, A., \& Aldakhil, A. (2012). Employee Engagement and Strategic Communication in Saudi Arabian Banks. IBIMA Business Review, 1-9.

2. Alanazi, F. M., \& Rodrigues, A. (2003). Power bases and attribution in three cultures. The Journal of Social Psychology, 143, 375-395.

3. Alderfer, C. P. C. P., \& Smith, K. K. K. (1982). Studying intergroup relations embedded in organizations. Administrative Science Quarterly, 27(1), 35-65.

4. Al-Khaldi, M. A., \& Wallace R. S. (1999). The influence of attitudes on personal computer utilization among knowledge workers: the case of Saudi Arabia. Information and Management, 36(1), 185 -204 .

5. Almunajjed, M. (2010). Women 's Employment in Saudi Arabia A Major Challenge. Booz \& Company Inc. Retrieved from

http://www.ideationcenter.com/media/fi le/Womens_Employment_in_Saudi_Arabia _FINAL.pdf

6. Al-saggaf, Y. (2004). The Effect of Online Community on Offline Community in Saudi Arabia. Ejisdc, 1-16.

7. Al-Shaikh, F. N. (2003). The practical reality theory and business ethics in nonWestern context: evidence from Jordan. Journal of Management Development, 22(8), 679-693.

8. Al Raisi et, al.(2011). E-Performance Systems: AMethod of Measuring Performance. International Journal of Web Portals. Volume 3, Issue 1. 2011

9. Bakker, A. B., \& Demerouti, E. (2007). The Job Demands Resources model: State of the art. Journal of Managerial Psychology (Vol. 22)
10. Barkhuizen, E.N., \& Rothmann, S. (2006). Work engagement of academic staff in South African higher education institutions. Management Dynamics, 15(1), 38-48.

11. Barnett, C.S., \& Pratt, M.G. (2000). From threat-rigidity to flexibility: Toward a learning model of autogenic Crisis in organizations. Journal of Organizational Change Management , 13: 74-88.

12. Bland, M. J., and Altman, D. (1986). Statistical methods for assessing agreement between two method of clinical measurement. Lancet 327, 307310. doi: 10.1016/S0140-6736(86)908378

13. Blessing and White. (2011, January). Employee engagement report 2011. New Jersey:Author. [Online] Available http:// www.blessingwhite.com/content/reports /

14. Branine, M., \& Pollard, D. (2010). Human resource management with Islamic management principles: dialectic for a reverse diffusion in management. Personal Review, 39 (6):712-727

15. Caplan, J. (2013) Strategic Talent Development. Develop and engage all your people for business success. London.UK. Cogan Page.

16. Christian, M. S., Garza, A. S., \& Slaughter, J. E. (2011). Work engagement: A quantitative review and test of its relations with task and contextual performance. Personnel Psychology, 64(1), 89-136.

17. Constable, S., Coats, D., Bevan, S., \& Michelle, M. (2009). Good jobs. London. Retrieved from http://www.theworkfoundation.com/do wnloadpublication/report/226_226_good _jobs2.pdf

18. Corace, C. J. (2007). Engagement enrolling the quiet majority. Organization Development Journal, 25(2), 171-175. 
19. Crawford, C., Duckworth, K., Vignoles, A., \& Wyness, G. (2010). Young people's education and labour market choices aged $16 / 17$ to $18 / 19$. London. Retrieved from https://www.gov.uk/government/upload s/system/uploads/attachment_data/file/ 183355/DFE-RR182.pdf

20. Cropanzano, R \& Mitchell, M.S 2005, 'Social exchange theory: an interdisciplinary review', Journal of Management, vol. 31, pp. 874-900. Haid, M \& Jamie, S 2009, 'Employee engagement: maximizing organizational performance', viewed $25 \quad$ February 2011, <http://www.right.com/thoughtleadershi p/ research/employee-engagement--maximizing-organ level izationalperformance. pdf

21. D'Aprix, R. (2006). The Challenges of Employee Engagement: Throwing Rocks at the Corporate Rhinoceros. In T. Gillis (Ed.), The IABC Handbook of Organizational Communication (2nd ed., pp. 227-239). San Francisco: John Wiley \& Sons.

22. Dadfar, A., Norberg, R., Helander, E., Schuster, S. and Zufferey, A. (2003), Intercultural Aspects of

23. Doing Business with Saudi Arabia, Linkoping University, Linkoping.

24. Dessler, G. (2005). Human Resource Management (10th ed.). Pearson/Prentice Hall. Demovsek, D. (2008). Employee Retention Through Employee Engagement. International Journal of Business and Management Invention ISSN (Online): 2319 - 8028, ISSN (Print): 2319 -801X www.ijbmi.org Volume 2 Issue 8\| August. 2013\|PP.09 16

25. Glaser, B. G., \& Strauss, A. L. (1967). The Discovery of Grounded Theory: Strategies for Qualitative Research. Aldine (Vol. 1). Chicago.

26. Frese, M. (2008). The changing nature of work. In N. Chmiel (Ed.), An introduction to work and organizational psychology (pp. 397-414). Oxford: Blackwell.

27. FEARON C, MCLAUGHLIN H \& MORRIS L. 2013. Conceptualising work engagement: An individual, collective and organisational efficacy perspective. European Journal of Training and Development 37(3):244-256

28. Furnham A., Petrides K. V., Jackson C. J, Cotter T. (2002). Do personality factor $s$ predict job satisfaction? Personality and individual differences, 33, 1325-1342

29. ENDRES GM \& MANCHENO-SMOAK L. 2008. The human resource craze: Human performance and employee engagement. Organization Development Journal 26(1):69-78.

30. Gruman, J. A., \& Saks, A. M. (2011). Performance management and employee engagement. Human Resource Management Review, 21(2), 123-136.

31. Harper, R. A., \& Subanthore, A. (2007). Saudi Arabia. In Modern World Nations (2nd ed.). New York: Chelsea House.

32. Hickson, D. J., \& Pugh, D. S. (1995). Management worldwide: The impact of societal culture on organizations around the globe. London: Penguin UK.

33. Hofstede, G. (1980). Culture's Consequences: International Differences in Work-Related Values. Beverly Hills, CA: Sage.

34. Hofstede, G., \& Minkov, M. (2010). Cultures and organizations: software of the mind: international cooperation and its importance for survival. (3rd ed., Vol. 1). New York: McGraw Hill Professional.

35. Idris, A. M. (2007). Cultural barriers to improved organizational performance in Saudi Arabia. S.A.M. Advanced Management Journal, 72(2), 36-54.

36. Iqbal, M., \& Molyneux, P. (2005). Thirty Years of Islamic Banking; History, performance and prospects. Prospects, 19(1), 190. 
37. Kate Pritchard, (2008) "Employee engagement in the UK: meeting the challenge in the public sector", Development and Learning in Organizations: An International Journal, Vol. 22 Issue: 6, pp.15-17, https://doi.org/10.1108/1477728081091 0302.

38. Kahn, W. A. (1990). PSYCHOLOGICAL CONDITIONS OF PERSONAL ENGAGEMENT AND DISENGAGEMENT AT WORK. Academy of Management Journal, 33(4), 692-724.

39. Kalliny, M., \& Gentry, L. (2007). Cultural Values Reflected in Arab and American Television Advertising. Journal of Current Issues \& Research in Advertising, 29(1), 15-32.

40. Kesby, D. (2008). Day-to-day leadership. Human Resource Management International Digest, 16(1), 3-5.

41. Kettell, B. (2011). Introduction to Islamic banking and finance. Wiley finance series.

42. KLASSEN RM, ALDHAFRI S, MANSFIELD CF, PURWANTO E, SIU AFY, WONG MM \& WOODS-

43. Lawrence, J. (2007). BUILDING AN EMPLOYEE SATISFACTION SURVEY. Personnel Today, 26-27.

44. Lockwood, RN 2007, Leveraging employee engagement for competitive advantage. Society for Human Resource Management, Alexandria, VA.

45. Levinson, E. (2007). Developing High Employee Engagement Makes Good Business Sense, accessed from www.interactionassociates.com/ideas/20 07/05/developing_high_employee_engage ment_makes_good_business_sense.php, on April 15. 2017.

46. Lloyd, R. (2008). Discretionary effort and the performance domain. The
Australian and New Zealand Journal of Organizational Psychology, 1 , 22-34.

47. Macey, W. H., \& Schneider, B. (2008). The Meaning of Employee Engagement. Industrial and Organizational Psychology, 1(January), 3-30.

48. MASSON RC, ROYAL MA, AGNEW TG \& FINE S. 2008. Leveraging employee engagement: The practical implications. Industrial and Organizational Psychology 1:56-59.

49. Maslach, C., Schaufeli, W. B., \& Leiter, M. P. (2001). Job burnout. Annual Review of Psychology, 52(1), 397422.

50. Maslach,C.,\&Leiter,M. P.(2008). Early predictors of burnout and work engagement. Journal of Applied Psychology, 93, 498-512.

51. May, D. R., Gilson, R. L., \& Harter, L. M. (2004). The psychological conditions of meaningfulness, safety and availability and the engagement of the human spirit at work. Journal of Occupational and Organizational Psychology, 77(1), 11-37.

52. HARTER JK \& SCHMIDT FL. 2008. Conceptual versus empirical distinctions among constructs: Implications for discriminant validity. Industrial and Organisational Psychology 1:36-39.

53. HARTER JK, SCHMIDT FL \& HAYES TL. 2002. Business-level-unit relationship between employee satisfaction, employee engagement, and business outcomes: A meta-analysis. Journal of Applied Psychology 87(2):268-279.

54. McBain, R 2007, 'The practice of engagement: research into current employee engagement practice', Strategic HR review, vol 6, no 6, pp 124-136.

55. Needle, D. 2004. Business in Context: An Introduction to Business and its Environment. Cengage Learning Business Press. Andover. 
56. NEWMAN DA \& HARRISON DA. 2008. Been there, bottled that: Are state and behavioral work engagement new and useful construct "wines"? Industrial and Organizational Psychology 1:31-35.

57. Özer, Gökhan and GÜNLÜK, Mehmet, The Effects of Discrimination Perception and Job Satisfaction on Turkish Public Accountants' Turnover Intention (June 17, 2010). African Journal of Business Management Vol. 4(8), pp. 1500-1509. Available at SSRN: https://ssrn.com/abstract=1975737

58. PARKER SK \& GRIFFIN MA. 2011. Understanding active psychological states: Embedding engagement in a wider nomological net and closer attention to performance. European Journal of Work and Psychology 20(1):60-70.

59. Robertson, C. J., Al-Khatib, J. A., AlHabib, M., \& Lanoue, D. (2001). Beliefs about the work in the

60. Middle East and convergence versus divergence of values. Journal of World Business, 36(3), 223-44.

61. Ram, P, \& Prabhakar, G 2011, 'The role of employee engagement in work-related outcomes', Interdisciplinary Journal of Research in Business, vol. 1, Issue. 3, March 2011, pp.47-61

62. Robinson, D., Perryman, S., \& Hayday, S. (2004). The drivers of employee engagement: Institute of Employment Studies Report 408. London.

63. Sackmann, S. a. (1991). Uncovering Culture in Organizations. The Journal of Applied Behavioral Science, 27(3), 295317.

64. Saks, A. M. \& Gruman, J. A. (2014). What do we really know about employee engagement?

65. Human Resource Development Quarterly, vol. 25(2), pp. 155 - 182.
66. Saks AM.2006. Antecedents and consequences of employee engagement. Journal of Managerial Psychology 21(7):600\#619.

67. Saks AM. 2008. The meaning and bleeding of employee engagem ent: How muddy is the water? Industrial and Organizational Psychology 1:40\#43.

68. Salah T. Madhi, Armando Barrientos, (2003) "Saudisation and employment in Saudi Arabia", Career Development International, Vol. 8 Issue: 2, pp.70-77, https://doi.org/10.1108/1362043031046 $\underline{5471}$

69. SADI, M. A. \& AL-BURAEY, M. A. 2009. A Framework of the Implementation Process: The Case of Saudization. International Management Review, 5,7084

70. SEPPÄLÄ P, MAUNO S, FELDT T, HAKANEN J, KINNUNEN U, TOLVANEN U \& SCHAUFELI W. 2009. The Construct Validity of the Utrecht Work Engagement Scale: Multisample and Longitudinal Evidence. Journal of Happiness Studies 10:459\#481

71. Schaufeli, W. B., \& Bakker, A. B. (2004). Job demands, job resources, and their relationship with burnout and engagement: A multi-sample study. Journal of Organizational Behavior, 25(3), 293-315.

72. Segal, B. (2009). Employee Engagement masks real differences in work attitudes between whites and minorities. New York: Sirota Survey Intelligence.

73. Shuck, MB 2010, 'Employee engagement: An examination of antecedent and outcome variables', PhD thesis, Florida International University, Miami, Florida, FIUElectronic Theses and Dissertations.

74. Shuck, B., \& Herd, A. M. (2012). Employee Engagement and Leadership: Exploring the Convergence of Two 
Frameworks and Implications for Leadership Development in HRD. Human Resource Development Review, 11(2), 156-181.

75. Shuck and Karen Wollard Employee Engagement and HRD: A Seminal Review of the Foundations Brad DOI: 10.1177/1534484309353560 December 20092010 9: 89 originally published online 2 Human Resource Development Review.

76. Strauss, A., \& Corbin, J. (1990). Basics of qualitative research: Grounded theory procedures and techniques. Newbury Park, CA: Sage.

77. Strauss, A., \& Corbin, J. (1994). Grounded theory methodology. Handbook of Qualitative Research. Sage.
78. Towers Perrin 2003, 'Working today: understanding what drives employee engagement'. Viewed15 August 2011, <http://www.towersperrin.com/tp/getw ebcachedoc /2003/200309/talent_2 003.pdf $>$.

79. Vance, R. J. (2006). Employee Engagement and Commitment. SHRM Foundation. USA.

80. Wildermuth, C. D. M. E. S., \& Pauken, P. D. (2008). A perfect match: decoding employee engagement - Part I: Engaging cultures and leaders. Industrial and Commercial Training, 40(3), 122-128.

81. Williams, A., Dobson, P., \& Walters, M. (1989). Changing culture New organizational approaches. London, UK: Institute of Personnel Management. 